\title{
The prognostic significance of long noncoding RNAs in non-small cell lung cancer: a meta-analysis
}

\author{
Wei Jing ${ }^{1, *}$, Nandi Li ${ }^{1, *}$, Yingchao Wang ${ }^{1}$, Xuefang Liu ${ }^{1}$, Shengjun Liao ${ }^{1}$, Hongyan \\ Chai ${ }^{1}$ and Jiancheng $\mathrm{Tu}^{1}$ \\ ${ }^{1}$ Department of Laboratory Medicine, Clinical Laboratory Medicine and Center for Gene Diagnosis, Zhongnan Hospital of \\ Wuhan University, Wuhan, China \\ * These authors have contributed equally to this work \\ Correspondence to: Jiancheng Tu, email: jianchengtu@whu.edu.cn \\ Hongyan Chai, email: chy1127@sina.com
}

Keywords: non-small cell lung cancer; long noncoding RNAs; prognosis; lymph node metastasis; meta-analysis

Received: November 01,2016 Accepted: December 08, $2016 \quad$ Published: December 15, 2016

\section{ABSTRACT}

Non-small cell lung cancer (NSCLC) is the most common type of lung cancer. The overall 5-year survival rate of patients is extremely low and to find a new marker is urgently needed. Numerous studies indicate that long noncoding RNAs (IncRNAs) abnormally express in cancers. However, the results have been disputed, especially in the aspects of tumor prognosis. Therefore, we performed this meta-analysis to systematically summarize the relationship between IncRNAs expression and NSCLC. A total of 34 eligible studies including $\mathbf{3 0}$ on overall survival, 10 on progression-free survival and $\mathbf{2 3}$ on clinicopathological features were identified from the databases. Our results indicated that the levels of IncRNAs were associated with the overall survival (OS; hazard ratios [HR], 1.43; 95\% confidence interval [95\% CI], 1.17-1.76; $P<0.001)$. However, there was no relationship between IncRNAs and progressionfree survival (PFS; hazard ratios [HR], 1.55; 95\% confidence interval [95\% CI], 0.912.63; $P=0.11$ ). Moreover, IncRNAs were related to Iymph node metastasis (odds ratios [OR], 1.70; 95\% confidence interval [95\% $\mathrm{CI}$ ], 1.03-2.80; $P=0.04$ ), while no association was observed with other characteristics. In conclusion, our present meta-analysis indicated that IncRNAs transcription levels may serve as a promising marker for prognosis of patients with NSCLC.

\section{INTRODUCTION}

Lung cancer is one of the most common malignant cancers worldwide, making up $18.2 \%$ of all malignant tumor mortality in the world $[1,2]$. Non-small cell lung cancer (NSCLC) is the most common type, accounting for about $85 \%$ of lung cancer [3]. To date, despite the effective treatments for patients have obtained, including surgical resection, systemic chemotherapy and targeted drugs, the prognosis of NSCLC remains still poor and the 5 -year survival rate is only $11-15 \%$, because the patients were diagnosed at advanced stages [4-6]. Metastasis and recurrence are the major causes of morbidity and death in NSCLC[7]. Lung cancer is a multi-factor, multi-step and complex process, which was related to many tumorrelated genes[8]. In NSCLC researches, several genetic biomarkers have been used, including non-coding RNAs (ncRNAs). Therefore, to identify sensitive and specific biomarkers for prognosis of patients with NSCLC is urgently needed.

Recently, advanced techniques discovered that more than $90 \%$ of the mammalian genome can be transcribed into short or long noncoding RNAs[9]. Long non-coding RNAs (lncRNAs) are defined as noncoding RNAs longer than 200 nucleotides with no protein-coding capacity [10]. Increasing evidences have pointed that lncRNAs play tremendous roles in epigenetics and cytobiological processes, including pre-transcription, post-transcription and cell proliferation, differentiation, apoptosis, and migration $[9,11,12]$. Aberrantly expressed lncRNAs have been found in various cancers. For example, the TGF- $\beta$-activated lncRNA (lncRNA-ATB), is significantly 
increased in hepatocellular carcinoma and associated with poor prognosis [13]. In 2016, Han et al [10] found that circulating long noncoding RNA GAS5 could be served as a biomarker in breast cancer to assess the surgical effects. In gastric cancer, knockdown of lncRNA X-inactive specific transcript (XIST) could reduce the mRNA and protein levels of EZH2 and suppress the colony formation and invasion ability stimulated by miR-101[14]. Meanwhile, recent studies have shown that lncRNAs could serve as potential diagnostic and prognostic biomarkers for NSCLC.

To date, there are some lncRNAs have been confirmed to aberrantly expressed in NSCLC, such as MALAT1[15], H19[16], and SPRY4-IT1[17]. In 2016, Lu et al [18] elaborated that there was a positive correlation between the expression levels of CDKN2B antisense RNA 1 (ANRIL) and c-Myc, and decreased ANRIL significantly inhibited NSCLC cell proliferation. BRAF activated non-coding RNA (BANCR) actively functioned as a regulator of epithelial-mesenchymal transition (EMT) through inducing E-cadherin expression, and decreasing $\mathrm{N}$-cadherin, Vimentin. The results suggested that BANCR could be a biomarker for poor prognosis of NSCLC [19]. CAR intergenic 10 (CAR10) a novel lncRNA, could bind and stabilize transcription factor Y-box-binding protein 1 (YB-1), leading to up-regulation of the epidermal growth factor receptor (EGFR) and proliferation of lung cancer cells, and CAR10-YB-1 represented a potential therapeutic target in NSCLC[11]. Numbers of researches were done to explore the prognostic value of lncRNAs in NSCLC. However, because the sample size and research programs, single study may be inaccurate and insufficient. Thus, we conducted a meta-analysis to evaluate the value of lncRNAs in the prognosis and clinical outcomes in NSCLC through larger sample size of patients.

\section{RESULTS}

\section{Study characteristics}

We searched 786 articles in the databases, as shown in the flow diagram (Figure 1). 725 records were removed after screening the titles and abstracts. Then because of no usable data or incomplete data, 27 papers were excluded. As a result, a total of 34 articles were in the current metaanalysis $[3,5,16,17,19-48]$, including 30 on overall survival (OS) $[3,5,16,17,19-43,48], 10$ on progressionfree survival (PFS) $[17,19,20,25,36,37,44-47]$ and 23 on clinicopathological features $[5,16,17,19,20,22-28$, 30, 32-40, 46].

Table 1 summarized the main characteristics of the included 34 studies ranging from 2003 to 2016, with a maximum sample size of 192 and a minimum sample size of 38 patients. Among these studies, 32 were from China, 1 from Japan and 1 from Germany. Because the cut-off definitions were various, the cut-off values were

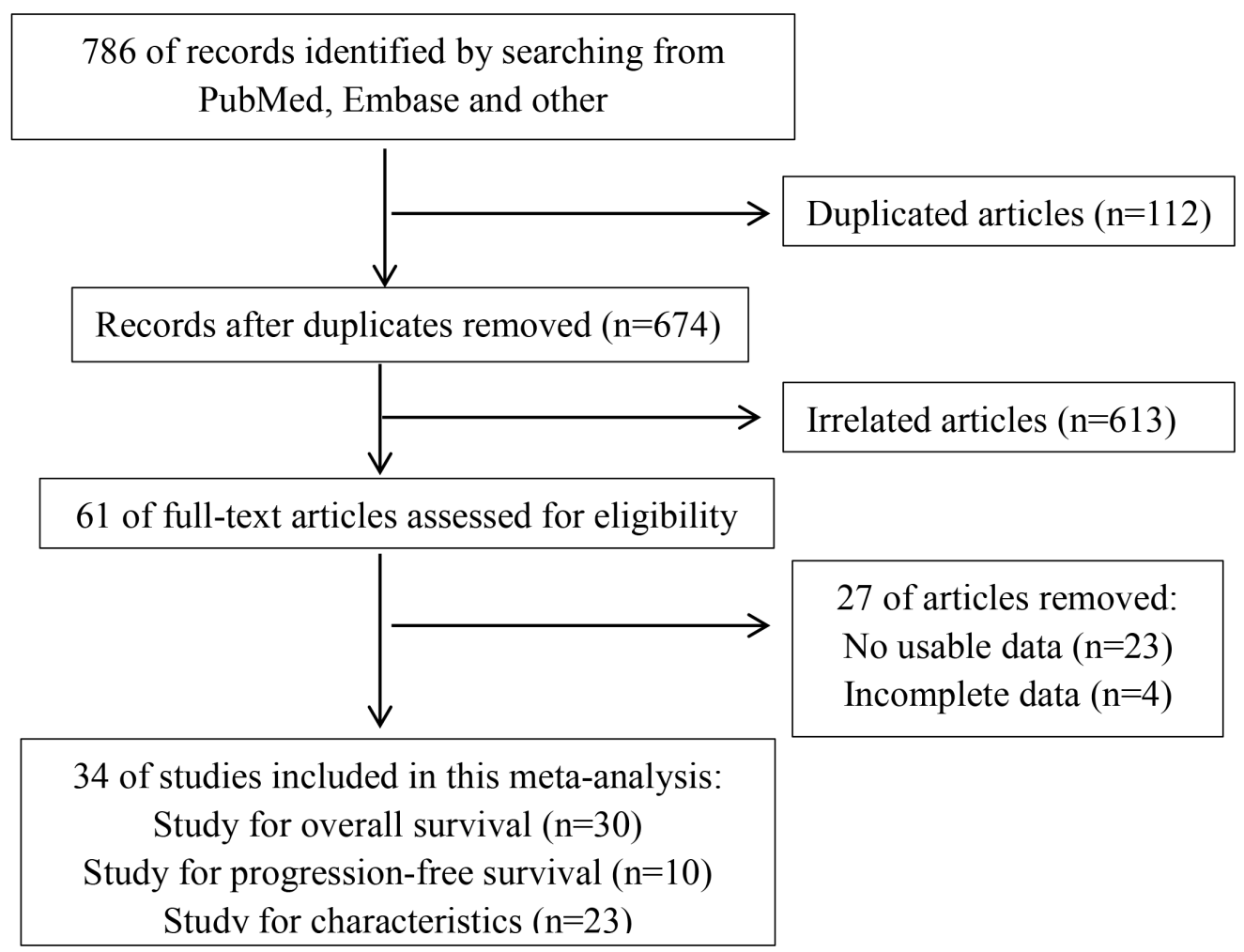

Figure 1: The flow diagram indicated the process of study selection. 
Table 1: Characteristics of studies included in this meta-analysis.

\begin{tabular}{|c|c|c|c|c|c|c|c|c|c|}
\hline Author & Year & Country & LncRNAs & Tumor type & Method & $\begin{array}{l}\text { Case number } \\
\text { (High/Low) }\end{array}$ & Outcome & Cut-off & $\begin{array}{l}\text { Follow- } \\
\text { up } \\
\text { months }\end{array}$ \\
\hline Hou & 2014 & China & Sox2ot & NSCLC & qRT-PCR & 47 & OS & Top quartile & 60 \\
\hline Deng & 2015 & China & AFAP1-AS1 & NSCLC & qRT-PCR & $66 / 55$ & OS & NA & 60 \\
\hline $\mathrm{Li}$ & 2016 & China & AGAP2-AS1 & NSCLC & qRT-PCR & $40 / 40$ & OS, PFS & Mean & 40 \\
\hline Luo & 2014 & China & CARLO-5 & NSCLC & qRT-PCR & $29 / 33$ & OS & Median & 80 \\
\hline $\mathrm{He}$ & 2016 & China & CASC2 & NSCLC & qRT-PCR & $38 / 38$ & OS & Median & 60 \\
\hline Sun & 2014 & China & BANCR & NSCLC & qRT-PCR & $53 / 60$ & OS, PFS & Fold-change & 40 \\
\hline Han & 2013 & China & GAS6-AS1 & NSCLC & qRT-PCR & $25 / 25$ & OS & Mean & 60 \\
\hline Zhang & 2016 & China & H19 & NSCLC & qRT-PCR & $25 / 25$ & OS & Median & 60 \\
\hline Lin & 2015 & China & ANRIL & NSCLC & qRT-PCR & $48 / 39$ & OS & Mean & 60 \\
\hline Zang & 2016 & China & Linc01133 & NSCLC & qRT-PCR & $34 / 34$ & OS, PFS & Mean & 40 \\
\hline Xie & 2014 & China & HMlincRNA717 & NSCLC & qRT-PCR & $49 / 69$ & OS & Mean & 80 \\
\hline Zhao & 2016 & China & SBF2-AS1 & NSCLC & qRT-PCR & $80 / 94$ & OS & Median & 70 \\
\hline Wang & 2015 & China & UCA1 & NSCLC & qRT-PCR & $36 / 24$ & $\mathrm{OS}$ & NA & 80 \\
\hline $\mathrm{Lu}$ & 2013 & China & MEG3 & NSCLC & qRT-PCR & $21 / 21$ & $\mathrm{OS}$ & Median & 60 \\
\hline Fang & 2016 & China & XIST & NSCLC & qRT-PCR & $38 / 15$ & OS & 2.58 -fold & NA \\
\hline Han & 2015 & China & PANDAR & NSCLC & qRT-PCR & $70 / 70$ & OS & Mean & 60 \\
\hline $\mathrm{Nie}$ & 2014 & China & MVIH & NSCLC & qRT-PCR & $21 / 21$ & OS & Median & 40 \\
\hline Sun & 2016 & China & NEAT1 & NSCLC & qRT-PCR & $67 / 29$ & $\mathrm{OS}$ & 2 folds & 40 \\
\hline Zhang & 2014 & China & TUG1 & NSCLC & qRT-PCR & $96 / 96$ & $\mathrm{OS}$ & Median & 60 \\
\hline Yang & 2014 & China & PVT1 & NSCLC & qRT-PCR & $65 / 17$ & OS & Median & 60 \\
\hline Wan & 2016 & China & PVT1 & NSCLC & qRT-PCR & $56 / 49$ & OS, PFS & Median & 40 \\
\hline Sun & 2014 & China & SPRY4-IT1 & NSCLC & qRT-PCR & $60 / 61$ & OS, PFS & Median & 40 \\
\hline Wang & 2016 & China & \begin{tabular}{|l|} 
TUSC7 \\
\end{tabular} & NSCLC & qRT-PCR & $56 / 56$ & OS, PFS & Median & 80 \\
\hline Nie & 2016 & China & UCA1 & NSCLC & qRT-PCR & $39 / 73$ & OS & Youden index & 80 \\
\hline Zhang & 2014 & China & ZXF1 & NSCLC & qRT-PCR & $43 / 19$ & $\mathrm{OS}$ & Ratio $=2$ & 36 \\
\hline Yang & 2015 & China & ZXF2 & NSCLC & qRT-PCR & $20 / 20$ & $\mathrm{OS}$ & Median & 39 \\
\hline $\mathrm{Ji}$ & 2003 & China & \begin{tabular}{|l|} 
MALAT1 \\
\end{tabular} & NSCLC & qRT-PCR & $70 / 70$ & OS & Median & 100 \\
\hline Zhang & 2015 & China & Linc 01133 & LSCC & qRT-PCR & 39 & OS & Median & 60 \\
\hline Schmidt & 2011 & Germany & MALAT1 & LSCC & qRT-PCR & NA & OS & NA & 166 \\
\hline Wang & 2015 & China & Linc01207 & LAD & qRT-PCR & $49 / 11$ & OS & Fold of 5.78 & 75 \\
\hline Cheng & 2015 & China & UCA1 & NSCLC & qRT-PCR & $20 / 32$ & PFS & $2-\Delta C t=0.068$ & 25 \\
\hline Pan & 2016 & China & BC087858 & NSCLC & qRT-PCR & $12 / 26$ & PFS & $2-\Delta \mathrm{Ct}=0.142$ & 40 \\
\hline Nakagawa & 2013 & Japan & HOTAIR & NSCLC & qRT-PCR & $17 / 60$ & PFS & 2-fold & 50 \\
\hline Liu & 2013 & China & HOTAIR & LAD & qRT-PCR & $22 / 19$ & PFS & HSCORE $=74.2$ & 15 \\
\hline
\end{tabular}

LncRNA: Long non-coding RNA; NSCLC: Non-small cell lung cancer; LSCC: Lung squamous cell carcinoma; LAD: Lung adenocarcinoma; qRT-PCR: Quantities reverse transcription-polymerase chain reaction; OS: Overall survival; PFS: Progression-free survival; NA: Not available

different in these studies. Meanwhile, in the 34 studies, 23 articles performed the relationship between the expression of IncRNAs and gender $[5,16,17,19,20,22-28,30,32-$ $40,46], 16$ studies referred to the smoking history[5, $16,17,19,20,22,23,25,30,32-34,36,38-40], 17$ studies demonstrated that IncRNAs were correlated with histological classification[16, 17, 19, 20, 22-27, 30, 32-34, $36,37,46], 12$ studies were on tumor size[16, 17, 19, 20, $22,25,30,32,33,36-38]$, and 11 were about tumor-nodemetastasis (TNM) [16, 17, 19, 20, 22, 25, 32, 34, 36-38], while 22 studies reported that lncRNAs were significantly correlated with lymph node metastasis (LNM) $[5,16,17$, 19, 20, 22, 24-28, 30, 32-40, 46] (Table 2).

\section{Prognosis}

A total of 30 studies were reported that the expression levels of IncRNAs were related to OS. Hazard ratios (HRs) and $95 \%$ confidence interval $(95 \% \mathrm{CI})$ were extracted from these studies. Analysis showed that the expression levels of IncRNAs were associated with the OS of NSCLC patients $(\mathrm{HR}=1.43,95 \% \mathrm{CI}=1.17-1.76$, $P<0.001$, random-effect) (Figure 2). Because 2 articles reported the relationship between lncRNAs and LSCC patients' OS ( $\mathrm{HR}=1.92,95 \% \mathrm{CI}=1.25-2.94, P=0.003$, fixed-effect) and 1 article was about LAD (HR $=2.53$, 
Table 2: Association between high levels of IncRNAs and characteristics of patients with NSCLC.

\begin{tabular}{|c|c|c|c|c|c|c|c|}
\hline \multirow{2}{*}{ Characteristics } & \multirow{2}{*}{ Studies } & \multirow{2}{*}{$\begin{array}{l}\text { Case } \\
\text { number }\end{array}$} & \multirow{2}{*}{ Pooled OR(95\% CI) } & \multirow{2}{*}{$P$} & \multicolumn{2}{|c|}{ Heterogeneity } & \multirow{2}{*}{ References } \\
\hline & & & & & $I^{2}$ & $P$ & \\
\hline $\begin{array}{l}\text { Gender } \\
\text { (male vs female) }\end{array}$ & 23 & 2111 & $1.00(0.83,1.19)$ & 0.96 & $0 \%$ & 0.63 & {$[5,16,17,19,20,22-28,30,32-40,46]$} \\
\hline $\begin{array}{l}\text { Smoking History } \\
\text { (never vs ever) }\end{array}$ & 16 & 1401 & $0.91(0.73,1.14)$ & 0.43 & $42 \%$ & 0.04 & $\begin{array}{l}{[5,16,17,19,20,22,23,25,30,32-34} \\
36,38-40]\end{array}$ \\
\hline $\begin{array}{l}\text { Histological classification } \\
\text { (LSCC vs LAD) }\end{array}$ & 17 & 1634 & $1.03(0.84,1.26)$ & 0.77 & $39 \%$ & 0.05 & $\begin{array}{l}{[16,17,19,20,22-27,30,32-34,36,37,} \\
46]\end{array}$ \\
\hline $\begin{array}{l}\text { Tumor size } \\
(\leq 3 \text { vs }>3)\end{array}$ & 6 & 519 & $0.45(0.17,1.25)$ & 0.13 & $85 \%$ & $<0.001$ & {$[16],[25],[33],[36],[40],[41]$} \\
\hline$(\leq 5$ vs $>5)$ & 6 & 529 & $0.61(0.18,2.01)$ & 0.42 & $90 \%$ & $<0.001$ & {$[17],[19],[23],[28],[35],[39]$} \\
\hline $\begin{array}{l}\text { TNM stage } \\
\text { (I-II vs III-IV) }\end{array}$ & 11 & 1091 & $0.63(0.28,1.44)$ & 0.27 & $89 \%$ & $<0.001$ & {$[16,17,19,20,22,25,32,34,36-38]$} \\
\hline $\begin{array}{l}\text { Lymph node metastasis } \\
\text { (presence vs absence) }\end{array}$ & 22 & 2036 & $1.70(1.03,2.80)$ & 0.04 & $85 \%$ & $<0.001$ & $\begin{array}{l}{[5,16,17,19,20,22,24-28,30,32-40} \\
46]\end{array}$ \\
\hline
\end{tabular}

LSCC: Lung squamous cell carcinoma; LAD: Lung adenocarcinoma; TNM: Tumor node metastasis; $\mathrm{I}^{2}>50 \%$ with the randomeffects model; $\mathrm{I}^{2}<50 \%$ with the fixed-effects model.

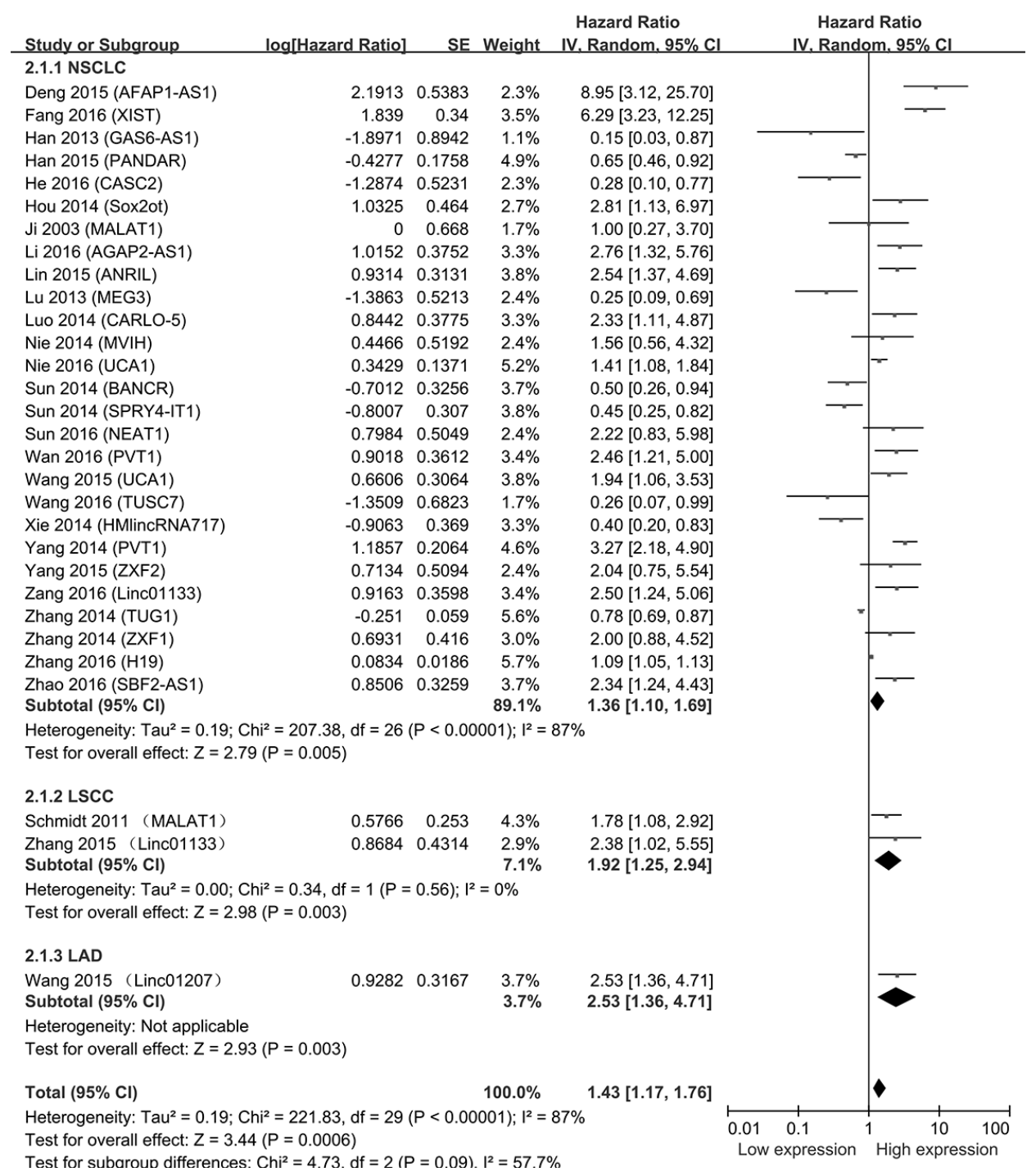

Figure 2: Forest plot of studies evaluating hazard ratios of IncRNAs expression and the overall survival in NSCLC. The point estimate is bounded by a 95\% confidence interval, and the perpendicular line represents no increased risk for the outcome. NSCLC: Non-small cell lung cancer; LSCC: Lung squamous cell carcinoma; LAD: Lung adenocarcinoma. 
$95 \% \mathrm{CI}=1.36-4.71, P=0.003$, fixed-effect $)$ in the enrolled 30 studies, we performed the subgroup analysis. From the forest plot, the increased expressions of AFAP1-AS1, XIST, Sox2ot, AGAP2-AS1, ANRIL, CARLO-5, MVIH, UCA1, NEAT1, PVT1, ZXF2, Linc01133, ZXF1, H19, SBF2-AS1, MALAT1 and Linc01207 were associated with poor prognosis. Besides, GAS6-AS1, PANDAR, CASC2, MEG3, BANCR, SPRY4-IT1, TUSC7, HMlincRNA717 and TUG1 were correlated to poor prognosis with the decreased expression of lncRNAs in NSCLC.

In the enrolling studies, UCA1, PVT1 and MALAT1 were investigated in two researches, other lncRNAs were performed in single study. Then we conducted a metaanalysis on the relationship between the expressions of UCA1/PVT1/MALAT1 and the OS of patients with NSCLC. We found that the high levels of UCA1 were associated with a poor $\mathrm{OS}(\mathrm{HR}=1.49,95 \% \mathrm{CI}=1.16$ $1.90, P=0.002$, fixed-effect) (Figure 3A). Meanwhile, a poor prognosis in NSCLC was found in the increased levels of PVT1 and MALAT1 (PVT1: HR $=3.05,95 \%$ $\mathrm{CI}=2.15-4.34, P<0.001$, fixed-effect) (MALAT1: HR = $1.66,95 \% \mathrm{CI}=1.04-2.63, P=0.03$, fixed-effect) (Figure 3B-3C).

10 studies enrolling 807 patients indicated that
lncRNAs expression was related to the PFS in NSCLC. The up-regulated expression of UCA1, AGAP2-AS1, BC087858, HOTAIR, PVT1 and Linc01133 had a relatively poor prognosis, the decreased expressions of BANCR, SPRY4-IT1 and TUSC7 were related to poor prognosis. 1 study demonstrated that the relationship between the levels of lncRNA and LAD (HR $=1.96$, $95 \% \mathrm{CI}=1.01-3.80, P=0.05$, fixed-effect). However, the expression of lncRNAs was not associated with the patients' $\mathrm{PFS}$ in the enrolling studies $(\mathrm{HR}=1.55,95 \% \mathrm{CI}$ $=0.91-2.63, P=0.11$, random-effect) (Figure 4).

\section{Correlation of IncRNAs with clinicopathological characteristics}

As shown in Table 2, we performed a meta-analysis to evaluate the relationship between the transcription levels of lncRNAs and clinicopathological characteristics of patients with NSCLC. Odds ratios $(\mathrm{OR})>1$ stated that high levels of lncRNAs might be a risk factor in the features. Our results demonstrated that the high lncRNA expressions were significantly related to LNM $(\mathrm{OR}=$ $1.70,95 \% \mathrm{CI}=1.03-2.80, P=0.04$, random-effect $)$.

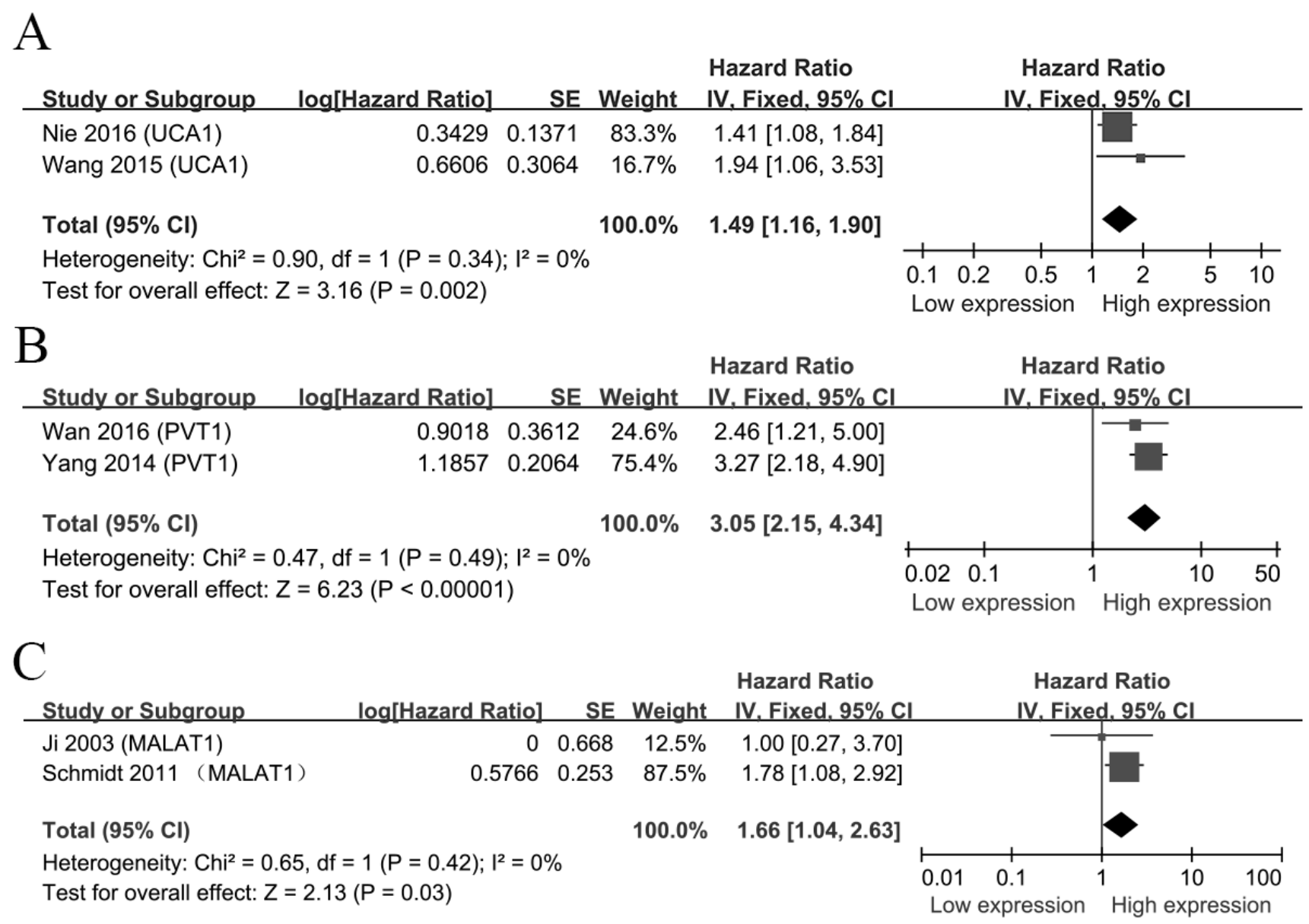

Figure 3: Forest plots of studies evaluating hazard ratios of up-regulated IncRNAs and the overall survival of NSCLC patients. A. UCA1; B. PVT1. C. MALAT1. 
Unfortunately, there was no correlation in gender $(\mathrm{OR}=$ $1.00,95 \% \mathrm{CI}=0.83-1.19, P=0.96$, fixed-effect), smoking history $(\mathrm{OR}=0.91,95 \% \mathrm{CI}=0.73-1.14, P=0.43$, fixedeffect), histological classification $(\mathrm{OR}=1.03,95 \% \mathrm{CI}=$ $0.84-1.26, P=0.77$, fixed-effect), tumor size $(\leq 3 \mathrm{~cm}$ vs $>3$ $\mathrm{cm}: \mathrm{OR}=0.45,95 \% \mathrm{CI}=0.17-1.25, P=0.13$, randomeffect) $(\leq 5 \mathrm{~cm}$ vs $>5 \mathrm{~cm}: \mathrm{OR}=0.61,95 \% \mathrm{CI}=0.18$ 2.01, $P=0.42$, random-effect), TNM (OR $=0.63,95 \%$ $\mathrm{CI}=0.28-1.44, P=0.27$, random-effect) (Supplementary Figure 1).

\section{Publication bias and sensitivity analysis}

Begg's test was used to evaluate the publication bias, respectively (Figure 5). In our meta-analysis, Begg's test indicated there were no publication bias in all groups, due to all the values of $P>0.05$. We used Stata11.0 software to perform sensitivity analysis to assess whether the individual studies affected the overall results. The results indicated that individual study had little influence on our final results (Figure 6), and demonstrated that our analysis was relatively stable and credible.

\section{DISCUSSION}

NSCLC is one of the leading causes of cancerrelated death[33]. Identification of early disease indicators for prognosis is urgently required. Recently, mounting evidence demonstrated that lncRNAs dysregulation was involved in cancers [36]. H19 which was a direct target of oncogene c-Myc was an independent predictor for OS, as well as the TNM stage [16]. TUG1 was an important prognostic factor for NSCLC patients. In addition, knockdown of TUG1 was found to result in anti-apoptotic activity in NSCLC [34]. For cancer researches, most of cancer associated lncRNAs could be effective prognostic biomarkers and even therapeutic targets[43]. Therefore, we performed a meta-analysis to evaluate the association between lncRNAs and prognosis of patients with NSCLC.

Accumulating studies elaborated that the association between lncRNAs and NSCLC. In 2013, Lu et al [29] suggested that MEG3 could be considered as a negative prognostic factor for NSCLC patients and an indicative of poor survival rates. Meantime, the decreased levels of CASC2 predicted a poor prognosis and could be as an independent predictor for OS [22]. In our meta-analysis, we assessed the prognostic role of IncRNAs in NSCLC. Our results indicated that high expressions of lncRNAs represented a risk factor for OS in NSCLC. From these results, lncRNAs could be as biomarkers for the prognosis of NSCLC. Previous study indicated that TUSC7 acted as a growth suppressor in NSCLC through inhibiting the p21/p27, and low TUSC7 expression had a shorter PFS. Unfortunately, there was no relationship between lncRNAs expression and PFS in our meta-analysis. Therefore,

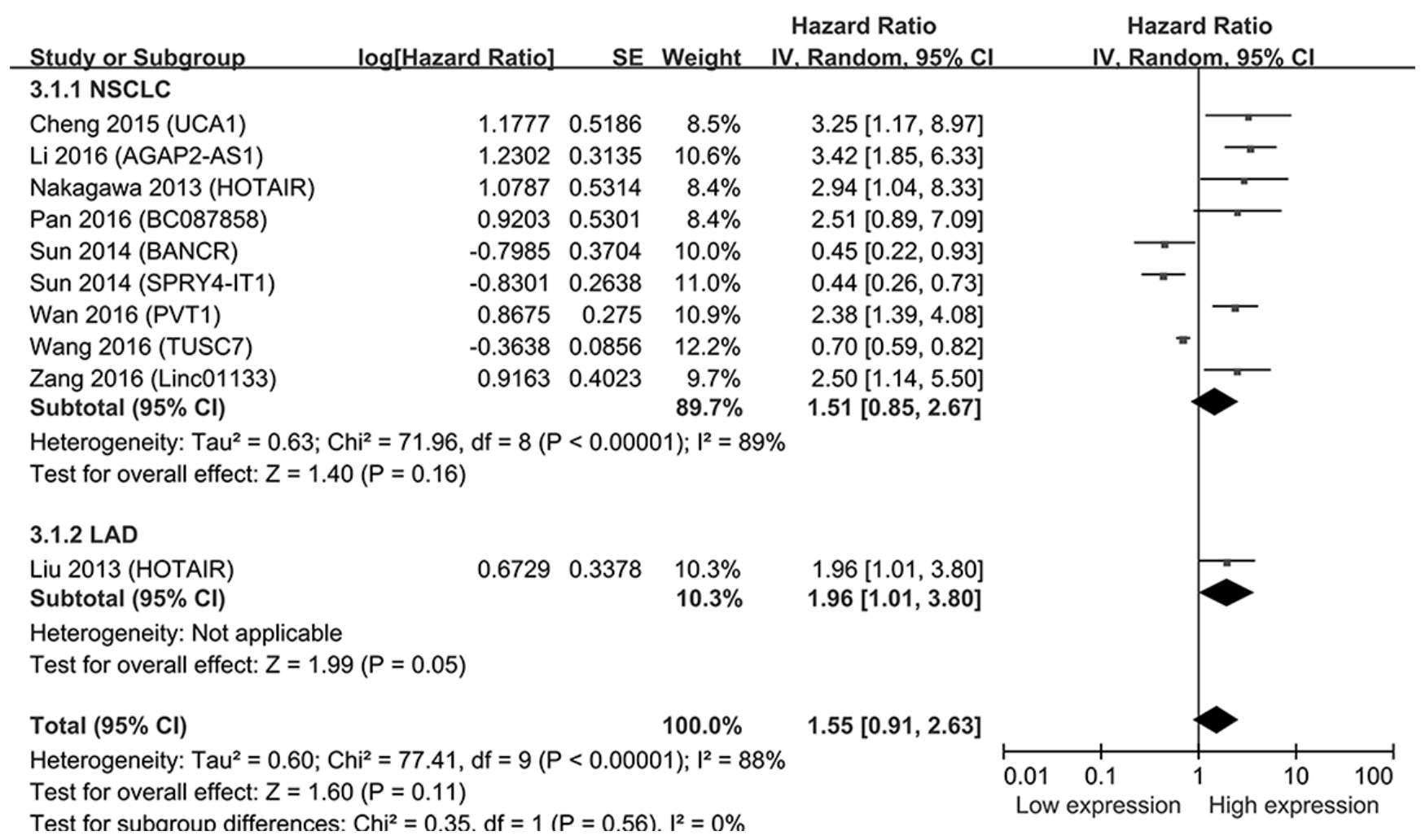

Figure 4: Forest plot of studies evaluating hazard ratios of IncRNAs expression and the progression-free survival in NSCLC. The point estimate is bounded by a 95\% confidence interval, and the perpendicular line represents no increased risk for the outcome. NSCLC: Non-small cell lung cancer; LAD: Lung adenocarcinoma. 
A

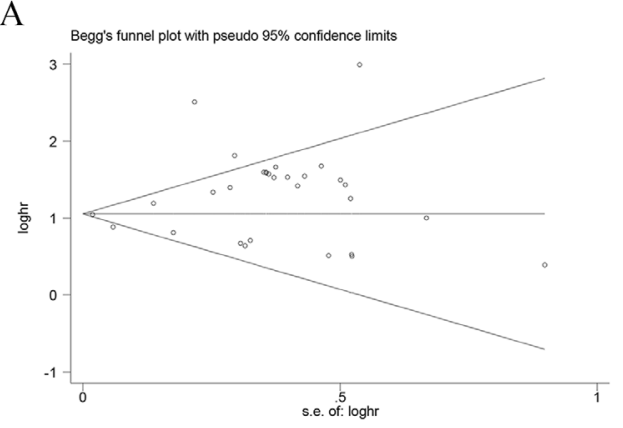

$\mathrm{C}$

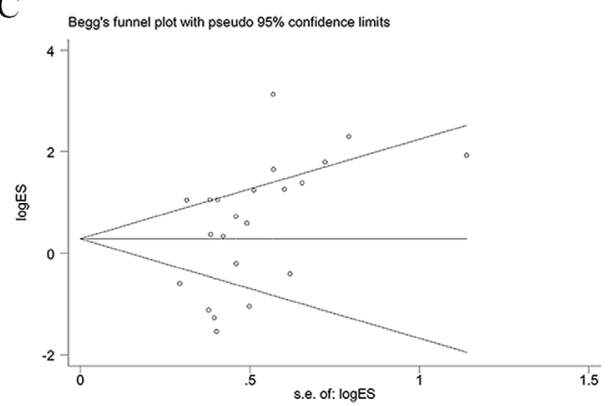

$\mathrm{E}$

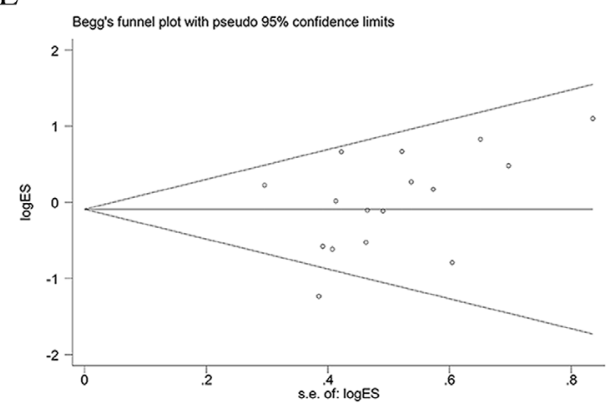

G

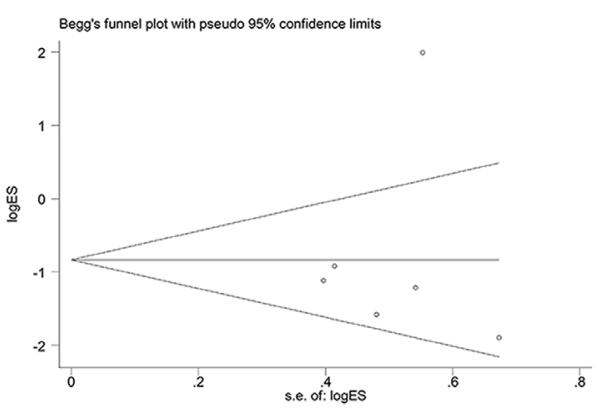

I Begg's funnel plot with pseudo $95 \%$ confidence limits

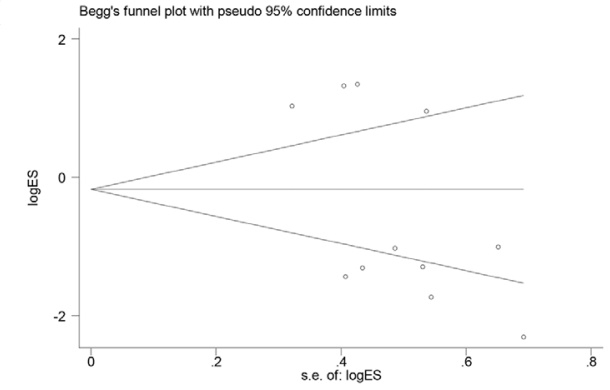

B

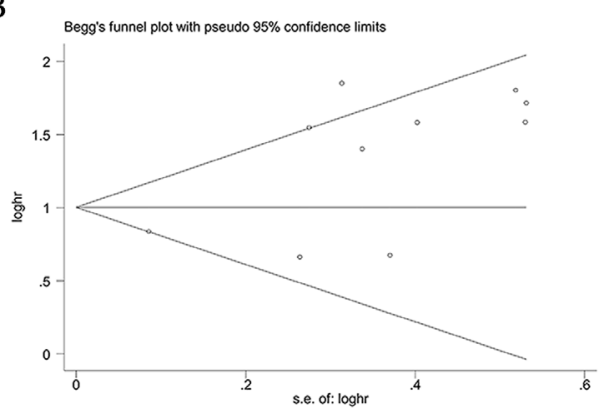

D

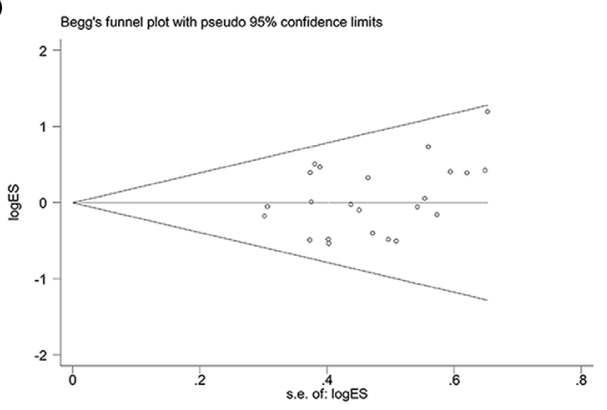

$\mathrm{F}$

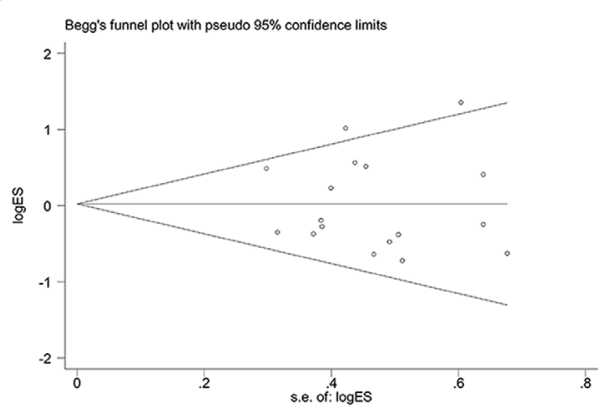

$\mathrm{H}$

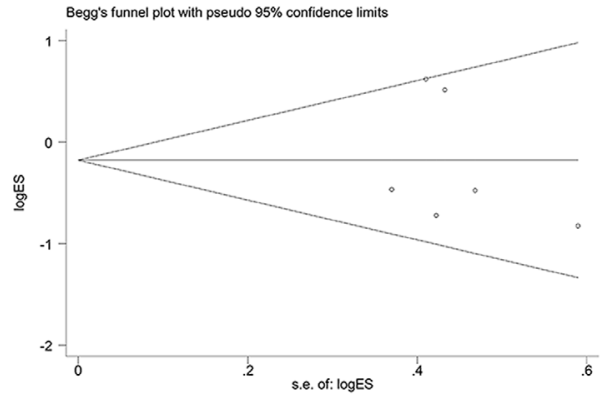

Figure 5: Begg's test for publication bias. A. overall survival; B. progression-free survival; C. lymph node metastasis; D. gender; E. smoking history; F. histological classification; G. tumor size $(\leq 3 v s>3)$; H. tumor size $(\leq 5 v s>5)$; I. TNM stage. 

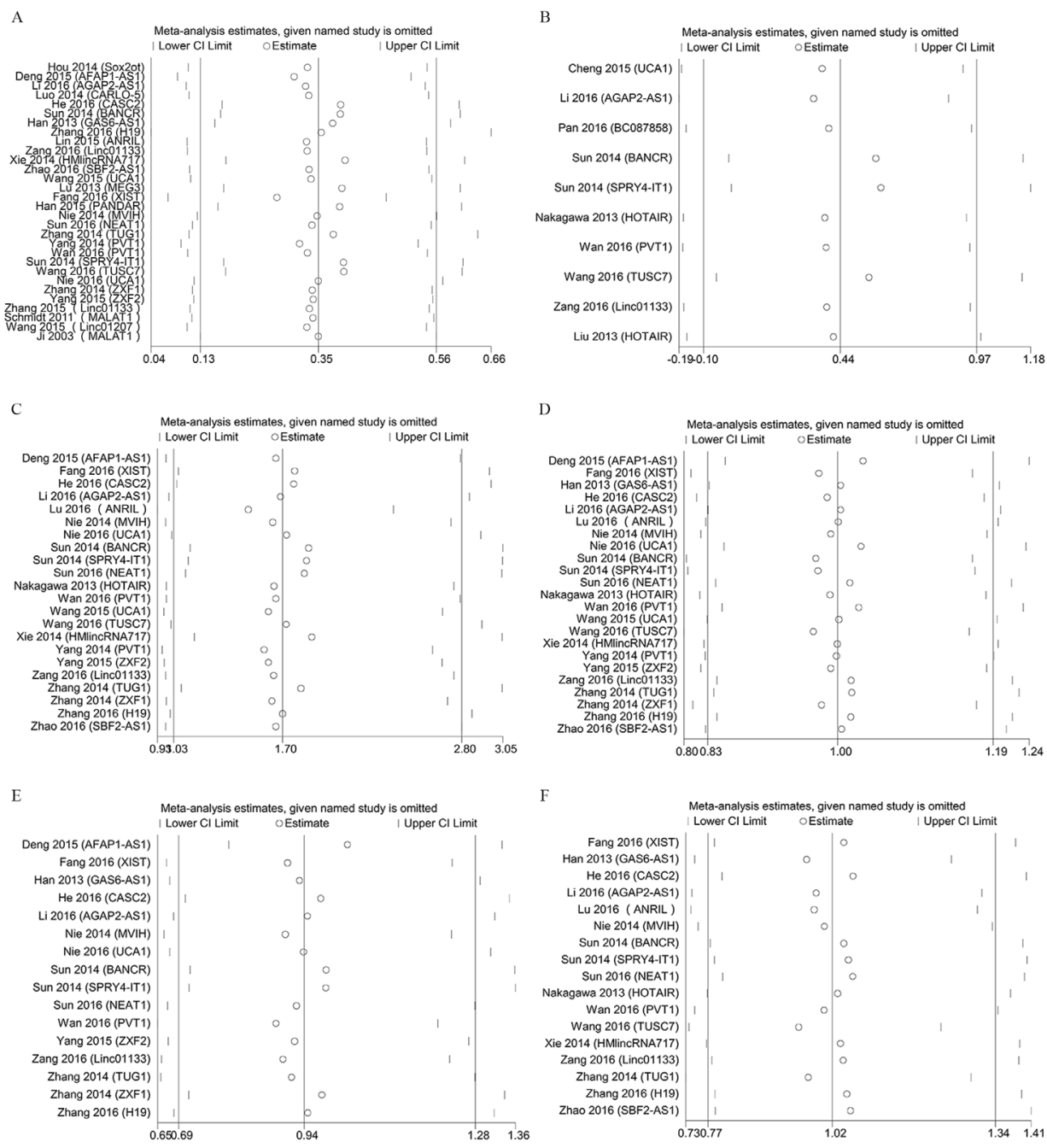

$\mathrm{H}$
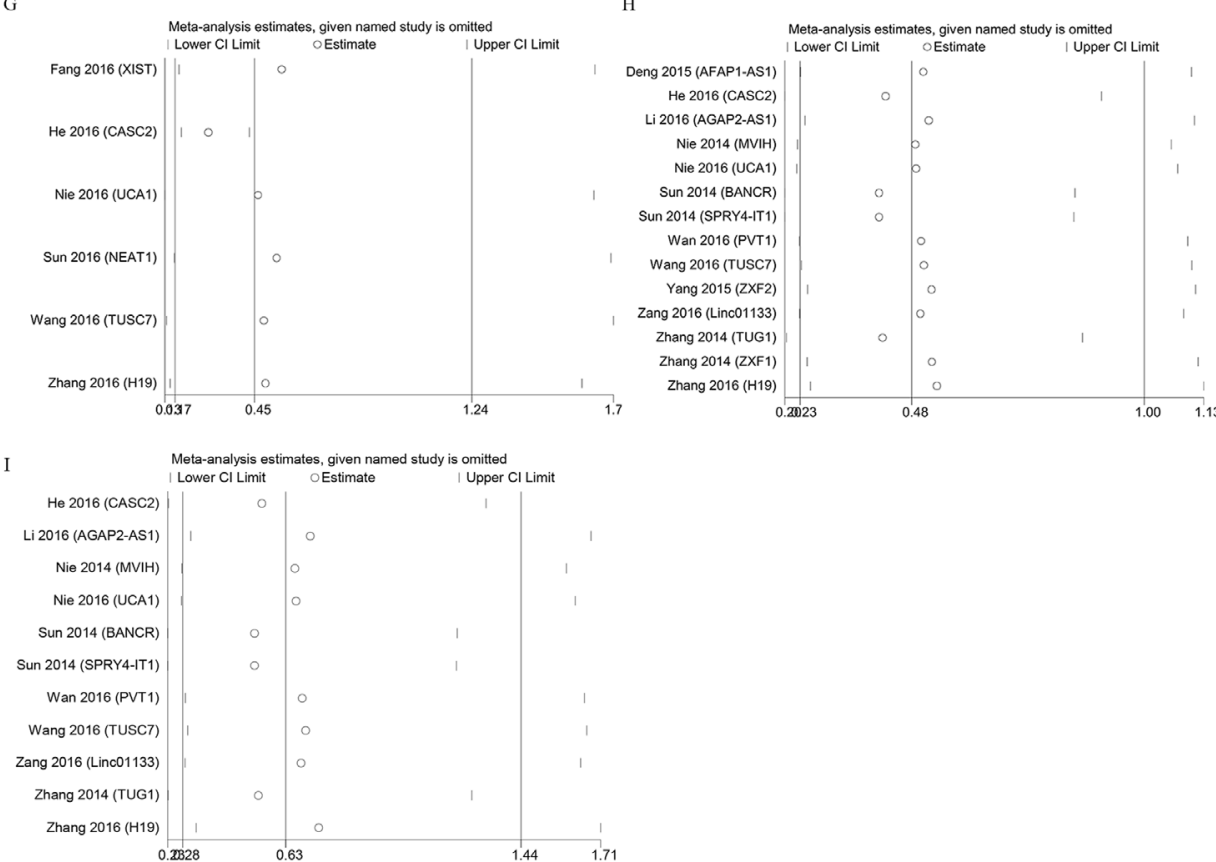

Figure 6: Sensitivity analyses of the studies. A. overall survival; B. progression-free survival; C. lymph node metastasis; D. gender; E. smoking history; F. histological classification; G. tumor size ( $\leq 3 v s>3)$; H. tumor size $(\leq 5 v s>5)$; I. TNM stage. 
further large-scale studies should be conducted.

In our meta-analysis, UCA1, PVT1 and MALAT1 were detected in two researches, and with the high levels of the three lncRNAs, the prognosis rate was low in NSCLC. UCA1 is originally identified in bladder transitional cell carcinoma. In 2016, Nie et al [38] revealed that UCA1 could promote NSCLC progression through functioning as miR-193a-3p sponge. Meanwhile, they found that UCA1-miR-193a-3p-ERBB4 signaling pathway might participate in the development of NSCLC. PVT1 is increased in the NSCLC patients, and the high expression of PVT1 was related with the poor prognostic outcome of cancer patients. Furthermore, PVT1 could decrease the levels of large tumor suppressor kinase 2 (LATS2), which could inhibit the growth and motility in NSCLC cells. Researchers also demonstrated that PVT1/ EZH2/LATS2 could be considered as a new therapeutic target for patients with NSCLC [36]. Li et al [15] found that MALAT1 inhibited miR-204 expression and promoted the progress of metastasis. Our results indicated that these three lncRNAs had a significantly prognostic value in NSCLC.

Previous researches indicated that the expressions of IncRNAs were related to clinicopathological parameters in NSCLC, including TNM[30], tumor size[16], LNM[28] and some other features. However, in our meta-analysis, we only found that there was a relationship between the high level transcription of lncRNAs and LNM. In 2016, Sun et al [33] found that NEAT1 were associated with the TNM stage and tumor size in patients with NSCLC. The clinical pathological features of NSCLC patients revealed a significant association between increased MVIH expression and advanced pathological stage, LNM, and NSCLC tumor size. What is more, MVIH could promote cell proliferation and invasion in NSCLC cells [32]. Therefore, the possible reason for the uncorrelation between IncRNAs and other characters was the insufficient study for each lncRNA.

It should be stressed the limitations in our analysis. Most studies reported positive results, but those with negative results were generally less likely to be published. Then, the enrolling studies were only English researches, no other languages. In addition, there were insufficient data to fully confirm the association between lncRNAs and clinicopathological characteristics, which needs more studies. What is more, most of the population in our studies were Chinese, which also might affect the results. Recently, circulating lncRNAs were detected to evaluate their diagnostic significance in NSCLC[49]. In 2016, Liang et al[49] indicated that GAS5 was decreased in NSCLC plasma and could be considered as a biomarker for the diagnosis of NSCLC. However, due to the presence of RNases, circulating RNA has been thought to be unstable, especially in cancer patients [50]. Meantime, the diagnostic studies about lncRNAs are not enough. Therefore, another limitation was the lack of diagnosis about lncRNAs in our meta-analysis.

In summary, our meta-analysis was firstly to evaluate the expressions of $\operatorname{lncRNAs}$ and clinical values of patients with NSCLC. Furthermore, the result indicated that the level transcription was related to LNM. Despite these limitations, there was a relationship between lncRNAs levels and OS in NSCLC, which demonstrated that lncRNAs could be potential prognostic markers for NSCLC. However, large-scale and comprehensive researches were needed to illuminate our results.

\section{MATERIALS AND METHODS}

\section{Publication search}

We searched the databases PubMed, Embase and Web of Science for studies published up to October 2016 to obtain relevant articles for the meta-analysis. The search strategy used both medical subject heading terms and freetext words to increase the sensitivity of the search. We mainly searched three key aspects "IncRNA", "cancer", and "lung", the detail search strategy was following: "Long noncoding RNA", "IncRNA", "LincRNA", "Long intergenic non-coding RNA" and "NSCLC", "non-small cell lung cancer", "LAD", "lung adenocarcinoma", "LSCC", "lung squamous cell cancer". Meanwhile, the article covered was limited to human and English.

\section{Inclusion and exclusion criteria}

In this meta-analysis, eligible studies had to meet the following standards: patients in the study were diagnosed with lung cancer; researches were association between lncRNAs and lung cancer; the prognostic value of lncRNAs was investigated; the relationship between lncRNAs expression and overall survival or progressionfree survival was performed; sufficient published data were provided to calculate hazard ratios and $95 \%$ confidence interval. If there were duplicated data, we chose the most complete data or the most recent one. Exclusion criteria were as follow: studies without usable or insufficient data; case reports, reviews, letters and conference abstracts.

\section{Data extraction}

Two investigators extracted relevant data from the eligible studies independently, including the first author, year of publication, country, the LncRNAs, tumor type, method, case number, cut-off value and follow-up months. 


\section{Statistical analysis}

HRs and 95\% CIs were used to assess the association between lncRNAs and survival in NSCLC. An observed HR $>1$ implied a worse survival for the group with elevated lncRNAs expression. Conversely, HR $<1$ implied a worse survival for the group with decreased lncRNAs expression [51]. Meanwhile, Odds ratios and $95 \% \mathrm{CI}$ were used to evaluate the relationship between lncRNAs and clinicopathological features in these inclusive articles. The features included gender, lymph node status, tumor sizes, histological classification, smoking history and TNM. We used Revman5.3 Software (Revman, the Cochrane Collaboration) to perform the meta-analysis and evaluate heterogeneity between studies by Cochrane Q-test and P-values. If heterogeneity was present $\left(I^{2} \geq 50 \%\right.$ or $\left.P \leq 0.05\right)$, random-effect model was used to calculate pooled HRs or ORs. If not, the fixedeffect model was more appropriate $[52,53]$. The Stata 11.0 Software (Stata, College Station) was performed to evaluate the sensitivity and publication bias of the studies. Publication bias was evaluated by Begg's test, $P<0.05$ was considered statistically significant.

\section{ACKNOWLEDGMENTS}

This study was supported by the National Basic Research Program of China (973 Program) (2012CB720605). 2012 US-China Biomedical Cooperation Projection (81261120403/H09298).

\section{CONFLICTS OF INTEREST}

The authors declare no conflicts of interest.

\section{REFERENCES}

1. Torre LA, Siegel RL, Jemal A. Lung Cancer Statistics. Adv Exp Med Biol. 2016; 893: 1-19. doi: 10.1007/978-3-31924223-1_1.

2. Ferlay J, Shin HR, Bray F, Forman D, Mathers C, Parkin DM. Estimates of worldwide burden of cancer in 2008: GLOBOCAN 2008. Int J Cancer. 2010; 127: 2893-917. doi: 10.1002/ijc. 25516 .

3. Hou Z, Zhao W, Zhou J, Shen L, Zhan P, Xu C, Chang C, Bi H, Zou J, Yao X, Huang R, Yu L, Yan J. A long noncoding RNA Sox2ot regulates lung cancer cell proliferation and is a prognostic indicator of poor survival. Int J Biochem Cell Biol. 2014; 53: 380-8. doi: 10.1016/j.biocel.2014.06.004.

4. Youlden DR, Cramb SM, Baade PD. The International Epidemiology of Lung Cancer: geographical distribution and secular trends. J Thorac Oncol. 2008; 3: 819-31. doi: 10.1097/JTO.0b013e31818020eb.

5. Deng J, Liang Y, Liu C, He S, Wang S. The up-regulation of long non-coding RNA AFAP1-AS1 is associated with the poor prognosis of NSCLC patients. Biomed Pharmacother. 2015; 75: 8-11. doi: 10.1016/j.biopha.2015.07.003.

6. Reed MF, Molloy M, Dalton EL, Howington JA. Survival after resection for lung cancer is the outcome that matters. Am J Surg. 2004; 188: 598-602. doi: 10.1016/j. amjsurg.2004.07.037.

7. Wu Y, Lyu H, Liu H, Shi X, Song Y, Liu B. Downregulation of the long noncoding RNA GAS5-AS1 contributes to tumor metastasis in non-small cell lung cancer. Sci Rep. 2016; 6: 31093. doi: 10.1038/srep31093.

8. Minna JD, Roth JA, Gazdar AF. Focus on lung cancer. Cancer Cell. 2002; 1: 49-52.

9. Ponting CP, Oliver PL, Reik W. Evolution and functions of long noncoding RNAs. Cell. 2009; 136: 629-41. doi: 10.1016/j.cell.2009.02.006.

10. Han L, Ma P, Liu SM, Zhou X. Circulating long noncoding RNA GAS5 as a potential biomarker in breast cancer for assessing the surgical effects. Tumour Biol. 2016; 37: 684754. doi: 10.1007/s13277-015-4568-7.

11. Wei MM, Zhou YC, Wen ZS, Zhou B, Huang YC, Wang GZ, Zhao XC, Pan HL, Qu LW, Zhang J, Zhang C, Cheng $\mathrm{X}$, Zhou GB. Long non-coding RNA stabilizes the Y-boxbinding protein 1 and regulates the epidermal growth factor receptor to promote lung carcinogenesis. Oncotarget. 2016; 7: 59556-59571. doi: 10.18632/oncotarget.10006.

12. Jing W, Zhu M, Zhang XW, Pan ZY, Gao SS, Zhou H, Qiu SL, Liang CZ, Tu JC. The Significance of Long Noncoding RNA H19 in Predicting Progression and Metastasis of Cancers: A Meta-Analysis. Biomed Res Int. 2016; 2016: 5902678. doi: 10.1155/2016/5902678.

13. Yuan JH, Yang F, Wang F, Ma JZ, Guo YJ, Tao QF, Liu F, Pan W, Wang TT, Zhou CC, Wang SB, Wang YZ, Yang $\mathrm{Y}$, et al. A long noncoding RNA activated by TGF-beta promotes the invasion-metastasis cascade in hepatocellular carcinoma. Cancer Cell. 2014; 25: 666-81. doi: 10.1016/j. ccr.2014.03.010.

14. Chen DL, Ju HQ, Lu YX, Chen LZ, Zeng ZL, Zhang DS, Luo HY, Wang F, Qiu MZ, Wang DS, Xu DZ, Zhou ZW, Pelicano $\mathrm{H}$, et al. Long non-coding RNA XIST regulates gastric cancer progression by acting as a molecular sponge of miR-101 to modulate EZH2 expression. J Exp Clin Cancer Res. 2016; 35: 142. doi: 10.1186/s13046-016-04201.

15. Li J, Wang J, Chen Y, Li S, Jin M, Wang H, Chen Z, Yu W. LncRNA MALAT1 exerts oncogenic functions in lung adenocarcinoma by targeting miR-204. Am J Cancer Res. 2016; 6: 1099-107.

16. Zhang E, Li W, Yin D, De W, Zhu L, Sun S, Han L. c-Mycregulated long non-coding RNA H19 indicates a poor prognosis and affects cell proliferation in non-small-cell lung cancer. Tumour Biol. 2016; 37: 4007-15. doi: 10.1007/ s13277-015-4185-5.

17. Sun M, Liu XH, Lu KH, Nie FQ, Xia R, Kong R, Yang JS, 
Xu TP, Liu YW, Zou YF, Lu BB, Yin R, Zhang EB, et al. EZH2-mediated epigenetic suppression of long noncoding RNA SPRY4-IT1 promotes NSCLC cell proliferation and metastasis by affecting the epithelial-mesenchymal transition. Cell Death Dis. 2014; 5: e1298. doi: 10.1038/ cddis.2014.256.

18. Lu Y, Zhou X, Xu L, Rong C, Shen C, Bian W. Long noncoding RNA ANRIL could be transactivated by c-Myc and promote tumor progression of non-small-cell lung cancer. Onco Targets Ther. 2016; 9: 3077-84. doi: 10.2147/ ott.s102658.

19. Sun M, Liu XH, Wang KM, Nie FQ, Kong R, Yang JS, Xia R, Xu TP, Jin FY, Liu ZJ, Chen JF, Zhang EB, De $\mathrm{W}$, et al. Downregulation of BRAF activated non-coding RNA is associated with poor prognosis for non-small cell lung cancer and promotes metastasis by affecting epithelialmesenchymal transition. Mol Cancer. 2014; 13: 68. doi: 10.1186/1476-4598-13-68.

20. Li W, Sun M, Zang C, Ma P, He J, Zhang M, Huang Z, Ding Y, Shu Y. Upregulated long non-coding RNA AGAP2-AS1 represses LATS2 and KLF2 expression through interacting with EZH2 and LSD1 in non-smallcell lung cancer cells. Cell Death Dis. 2016; 7: e2225. doi: 10.1038/cddis.2016.126.

21. Luo J, Tang L, Zhang J, Ni J, Zhang HP, Zhang L, Xu JF, Zheng D. Long non-coding RNA CARLo-5 is a negative prognostic factor and exhibits tumor pro-oncogenic activity in non-small cell lung cancer. Tumour Biol. 2014; 35: 11541-9. doi: 10.1007/s13277-014-2442-7.

22. He X, Liu Z, Su J, Yang J, Yin D, Han L, De W, Guo R. Low expression of long noncoding RNA CASC2 indicates a poor prognosis and regulates cell proliferation in nonsmall cell lung cancer. Tumour Biol. 2016; 37: 9503-10. doi: 10.1007/s13277-016-4787-6.

23. Han L, Kong R, Yin DD, Zhang EB, Xu TP, De W, Shu YQ. Low expression of long noncoding RNA GAS6-AS1 predicts a poor prognosis in patients with NSCLC. Med Oncol. 2013; 30: 694. doi: 10.1007/s12032-013-0694-5.

24. Lin L, Gu ZT, Chen WH, Cao KJ. Increased expression of the long non-coding RNA ANRIL promotes lung cancer cell metastasis and correlates with poor prognosis. Diagn Pathol. 2015; 10: 14. doi: 10.1186/s13000-015-0247-7.

25. Zang C, Nie FQ, Wang Q, Sun M, Li W, He J, Zhang M, Lu KH. Long non-coding RNA LINC01133 represses KLF2, P21 and E-cadherin transcription through binding with EZH2, LSD1 in non small cell lung cancer. Oncotarget. 2016; 7: 11696-707. doi: 10.18632/oncotarget.7077.

26. Xie X, Liu HT, Mei J, Ding FB, Xiao HB, Hu FQ, Hu R, Wang MS. LncRNA HMlincRNA717 is down-regulated in non-small cell lung cancer and associated with poor prognosis. Int J Clin Exp Pathol. 2014; 7: 8881-6.

27. Zhao QS, Li L, Zhang L, Meng XW, Li LL, Ge XF, Li ZP. Over-expression of lncRNA SBF2-AS1 is associated with advanced tumor progression and poor prognosis in patients with non-small cell lung cancer. Eur Rev Med Pharmacol
Sci. 2016; 20: 3031-4.

28. Wang HM, Lu JH, Chen WY, Gu AQ. Upregulated lncRNA-UCA1 contributes to progression of lung cancer and is closely related to clinical diagnosis as a predictive biomarker in plasma. Int J Clin Exp Med. 2015; 8: $11824-$ 30.

29. Lu KH, Li W, Liu XH, Sun M, Zhang ML, Wu WQ, Xie WP, Hou YY. Long non-coding RNA MEG3 inhibits NSCLC cells proliferation and induces apoptosis by affecting p53 expression. BMC Cancer. 2013; 13: 461. doi: 10.1186/1471-2407-13-461.

30. Fang J, Sun CC, Gong C. Long noncoding RNA XIST acts as an oncogene in non-small cell lung cancer by epigenetically repressing KLF2 expression. Biochem Biophys Res Commun. 2016; 478: 811-7. doi: 10.1016/j. bbrc.2016.08.030.

31. Han L, Zhang EB, Yin DD, Kong R, Xu TP, Chen WM, Xia $\mathrm{R}$, Shu YQ, De W. Low expression of long noncoding RNA PANDAR predicts a poor prognosis of non-small cell lung cancer and affects cell apoptosis by regulating Bcl-2. Cell Death Dis. 2015; 6: e1665. doi: 10.1038/cddis.2015.30.

32. Nie FQ, Zhu Q, Xu TP, Zou YF, Xie M, Sun M, Xia R, Lu KH. Long non-coding RNA MVIH indicates a poor prognosis for non-small cell lung cancer and promotes cell proliferation and invasion. Tumour Biol. 2014; 35: 7587-94. doi: 10.1007/s13277-014-2009-7.

33. Sun C, Li S, Zhang F, Xi Y, Wang L, Bi Y, Li D. Long non-coding RNA NEAT1 promotes non-small cell lung cancer progression through regulation of miR-377-3p-E2F3 pathway. Oncotarget. 2016; 7: 51784-51814. doi: 10.18632/ oncotarget.10108.

34. Zhang EB, Yin DD, Sun M, Kong R, Liu XH, You LH, Han L, Xia R, Wang KM, Yang JS, De W, Shu YQ, Wang ZX. P53-regulated long non-coding RNA TUG1 affects cell proliferation in human non-small cell lung cancer, partly through epigenetically regulating HOXB7 expression. Cell Death Dis. 2014; 5: e1243. doi: 10.1038/cddis.2014.201.

35. Yang YR, Zang SZ, Zhong CL, Li YX, Zhao SS, Feng XJ. Increased expression of the lncRNA PVT1 promotes tumorigenesis in non-small cell lung cancer. Int J Clin Exp Pathol. 2014; 7: 6929-35.

36. Wan L, Sun M, Liu GJ, Wei CC, Zhang EB, Kong R, Xu TP, Huang MD, Wang ZX. Long Noncoding RNA PVT1 Promotes Non-Small Cell Lung Cancer Cell Proliferation through Epigenetically Regulating LATS2 Expression. Mol Cancer Ther. 2016; 15: 1082-94. doi: 10.1158/1535-7163. mct-15-0707.

37. Wang $Z$, Jin $Y$, Ren $H$, Ma X, Wang $B$, Wang $Y$. Downregulation of the long non-coding RNA TUSC7 promotes NSCLC cell proliferation and correlates with poor prognosis. Am J Transl Res. 2016; 8: 680-7.

38. Nie W, Ge HJ, Yang XQ, Sun X, Huang H, Tao X, Chen WS, Li B. LncRNA-UCA1 exerts oncogenic functions in non-small cell lung cancer by targeting miR-193a- 
3p. Cancer Lett. 2016; 371: 99-106. doi: 10.1016/j. canlet.2015.11.024.

39. Zhang L, Zhou XF, Pan GF, Zhao JP. Enhanced expression of long non-coding RNA ZXF1 promoted the invasion and metastasis in lung adenocarcinoma. Biomed Pharmacother. 2014; 68: 401-7. doi: 10.1016/j.biopha.2014.03.001.

40. Yang ZT, Li Z, Wang XG, Tan T, Yi F, Zhu H, Zhao JP, Zhou XF. Overexpression of Long Non-Coding RNA ZXF2 Promotes Lung Adenocarcinoma Progression Through c-Myc Pathway. Cell Physiol Biochem. 2015; 35: 2360-70. doi: $10.1159 / 000374038$.

41. Zhang J, Zhu N, Chen X. A novel long noncoding RNA LINC01133 is upregulated in lung squamous cell cancer and predicts survival. Tumour Biol. 2015; 36: 7465-71. doi: 10.1007/s13277-015-3460-9.

42. Schmidt LH, Spieker T, Koschmieder S, Schaffers S, Humberg J, Jungen D, Bulk E, Hascher A, Wittmer D, Marra A, Hillejan L, Wiebe K, Berdel WE, et al. The long noncoding MALAT-1 RNA indicates a poor prognosis in non-small cell lung cancer and induces migration and tumor growth. J Thorac Oncol. 2011; 6: 1984-92. doi: 10.1097/ JTO.0b013e3182307eac.

43. Wang G, Chen H, Liu J. The long noncoding RNA LINC01207 promotes proliferation of lung adenocarcinoma. Am J Cancer Res. 2015; 5: 3162-73.

44. Cheng N, Cai W, Ren S, Li X, Wang Q, Pan H, Zhao M, Li J, Zhang Y, Zhao C, Chen X, Fei K, Zhou C, et al. Long non-coding RNA UCA1 induces non-T790M acquired resistance to EGFR-TKIs by activating the AKT/ mTOR pathway in EGFR-mutant non-small cell lung cancer. Oncotarget. 2015; 6: 23582-93. doi: 10.18632/ oncotarget.4361.

45. Pan H, Jiang T, Cheng N, Wang Q, Ren S, Li X, Zhao C, Zhang L, Cai W, Zhou C. Long non-coding RNA BC087858 induces non-T790M mutation acquired resistance to EGFRTKIs by activating PI3K/AKT and MEK/ERK pathways and EMT in non-small-cell lung cancer. Oncotarget. 2016; 7: 49948-49960. doi: 10.18632/oncotarget.10521.
46. Nakagawa T, Endo H, Yokoyama M, Abe J, Tamai K, Tanaka N, Sato I, Takahashi S, Kondo T, Satoh K. Large noncoding RNA HOTAIR enhances aggressive biological behavior and is associated with short disease-free survival in human non-small cell lung cancer. Biochem Biophys Res Commun. 2013; 436: 319-24. doi: 10.1016/j. bbrc.2013.05.101.

47. Liu Z, Sun M, Lu K, Liu J, Zhang M, Wu W, De W, Wang $\mathrm{Z}$, Wang R. The long noncoding RNA HOTAIR contributes to cisplatin resistance of human lung adenocarcinoma cells via downregualtion of p21(WAF1/CIP1) expression. PLoS One. 2013; 8: e77293. doi: 10.1371/journal.pone.0077293.

48. Ji P, Diederichs S, Wang W, Boing S, Metzger R, Schneider PM, Tidow N, Brandt B, Buerger H, Bulk E, Thomas M, Berdel WE, Serve H, et al. MALAT-1, a novel noncoding RNA, and thymosin beta4 predict metastasis and survival in early-stage non-small cell lung cancer. Oncogene. 2003; 22: 8031-41. doi: 10.1038/sj.onc.1206928.

49. Liang W, Lv T, Shi X, Liu H, Zhu Q, Zeng J, Yang W, Yin J, Song Y. Circulating long noncoding RNA GAS5 is a novel biomarker for the diagnosis of nonsmall cell lung cancer. Medicine (Baltimore). 2016; 95: e4608. doi: 10.1097/md.0000000000004608.

50. Tsui NB, Ng EK, Lo YM. Stability of endogenous and added RNA in blood specimens, serum, and plasma. Clin Chem. 2002; 48: 1647-53.

51. Chen J, Chen Y, Gu L, Li X, Gao Y, Lyu X, Chen L, Luo G, Wang L, Xie Y, Duan J, Peng C, Ma X. LncRNAs act as prognostic and diagnostic biomarkers in renal cell carcinoma: a systematic review and meta-analysis. Oncotarget. 2016; 7: 74325-74336. doi: 10.18632/ oncotarget.11101.

52. DerSimonian R, Laird N. Meta-analysis in clinical trials. Control Clin Trials. 1986; 7: 177-88.

53. Mantel N, Haenszel W. Statistical aspects of the analysis of data from retrospective studies of disease. J Natl Cancer Inst. 1959; 22: 719-48. 